RASĀYAN J. Chem.

Vol. 13 | No. 3 |1637-1643| July - September | 2020 ISSN: 0974-1496 | e-ISSN: 0976-0083 | CODEN: RJCABP http://www.rasayanjournal.com http://www.rasayanjournal.co.in

\title{
PHYSICO-CHEMICAL ANALYSIS AND PRELIMINARY PHYTOCHEMICAL SCREENING OF CRUDE PLANT EXTRACTS OF Eclipta alba IN DISTRICT HARIDWAR
}

\author{
Sarvesh Kumar,2,*, Vijay Jyoti Kumar ${ }^{1}$ and Ranjit Singh ${ }^{2}$ \\ ${ }^{1}$ Department of Pharmaceutical Sciences, HNB Garhwal (A Central University), \\ Srinagar Garhwal, Uttarakhand \\ ${ }^{2}$ AVIPS Shobhit University, Gangoh Saharanpur (UP) \\ *E-mail: sarveshlohan@gmail.com
}

\begin{abstract}
Rasashastra is a topic about the elements and their medicinal effects. This addresses the use of different elements as bhasma in a refined form. Iron is commonly used in Ayurvedic literature to treat various illnesses such as Pandu (Anemia), Shotha (Oedema), Kamala (Jaundice) etc. It is really hard metal so it should be converted into bhasma for therapeutic use. No physical or chemical changes that occur during storage of the formulation which can affect the efficacy of Bhasma. Throughout the storage condition of the bhasma, Pharmaceutical and analytical tests were carried out to learn how to know changes in the chemical constitution at various levels during storage conditions of the bhasma. The present work was carried out to access the standard aspects of bhasma use. But some of the existing criteria adapted for evaluation such as organoleptic evaluations, physical evaluations (Loss on Drying, Ash value, Acid insoluble ash, Ash value extractive, Phytochemical screening), chemical evaluations (Qualitative determination of metals) make the bhasma generally appropriate. In the present study, we investigate the phytochemical screening in the Eclipta alba plant belonging to family Asteraceae, extracted with chloroform, methanol, ethyl acetate, nhexane and water using soxhlet and the Physico-chemical analysis like a loss on drying, total ash value, acid insoluble ash, water-soluble ash, water solubility and extractive value of methanol, ethyl acetate, petroleum ether and chloroform. Results showed that Eclipta alba was found complying LOD (85.5\% w/w), Total ash (15.625\%), Acid insoluble ash (26.984\%), water-soluble ash (29.32\%), Phytochemical screening showed alkaloids, flavonoids etc were present. Methanolic extractive value $8.4 \%$ was found. In this study evaluate the standards for the commonly used herbal formulation, which can be utilized in quality control of the formulation.
\end{abstract}

Keyword: Eclipta alba, Bhasma, Herbal Formulation, Phytochemical Screening, Physico-chemical properties.

(C) RASĀYAN. All rights reserved

\section{INTRODUCTION}

The plants and animals are the main sources of medicines used for therapy and preventions of diseases is as older as human culture. "A medicinal plant which contains substances in one or more of its organs that can be used for the therapeutic purpose or that are precursors for the synthesis of useful drugs". For centuries, traditionally therapeutic plants were used because of their cure and protective capability; some widely used plants determined for their study of chemical constituents and organic activities such as antioxidant, anti-inflammatory, anti-diabetic, anti-fungal, anti-bacterial, anti-cancer, anti-asthmatic, antiallergic \& cardiovascular action in an attempt to establish a scientific basis for their ethno-medical uses. ${ }^{2}$ Examples of some plants are used in traditional or as medicine is Achyranthes aspera (family: Amaranthaceae) traditionally used in cancer, the human brain, cardiovascular function, microbial infection, inflammation, pain, and many more, Ageratum conyzoides (family: Asteraceae) traditionally used in burns and wounds, infectious diseases, fever, arthritis. ${ }^{3}$ In particular, the operation against mosquito Aedes aegypti has been shown to have a hepatoprotective and radioprotective effect. ${ }^{4,5}$ Leaf of Acalypha acrogyna Pax (family: Euphorbiaceae), the root of Asparagus africanus (family: Asparagaceae), leaf of Brucea antidysenterica (family: Simaroubaceae), fresh fruit of Lycopersicon esculentum ssp (family: Solanaceae) used in cancer treatment ${ }^{6}$, quinine and quinidine from the bark of Cinchona species

Rasayan J. Chem., 13(3), 1637-1643(2020)

http://dx.doi.org/10.31788/RJC.2020.1335911 
RASĀYAN J. Chem.

Vol. 13 | No. 3 |1637-1643| July - September | 2020

(Family: Rubiaceae), digoxin from dried leaves of Digitalis lanata (Family: Scrophulariaceae), Vincristine and vinblastine from the dried whole plant Catharanthus roseus (Family: Apocynaceae), morphine and codeine from the air-dried milky exudates obtained by incising the unripe capsules of Papaver somniferum (Family: Papaveraceae) and atropine from dried leaves and flowering or fruiting tops of Atropa belladonna (Family: Solanaceae). ${ }^{7}$

Medicinal plants are a rich source of antimicrobial agents and play an important role in health services around the world. Eclipta alba (L.) is an annual herb belonging to the family Asteraceae and is commonly known as Bhringaraj or "King of hairs". In ayurvedic medicine, the leaf extract of $E$. alba is examined as a major liver supplement tonic, rejuvenating and especially good for the hair. E. alba also used in traditional treatment of many diseases like eczema, athlete foot, and dermatitis, etc. This plant is known to have various pharmacological properties and is traditionally used in the treatment of epilepsy. The juice of the plant is used for nausea. This is used for burns, swelling, and minor cuts and the fresh leaf juice is known to be highly very effective in blood coagulation. The leaves of $E$. alba are used against snake bites and scorpion stings. E. alba is a source of various compounds used in Phytopharmaceutical formulations of medicinal products used for the treatment of liver cirrhosis and infectious hepatitis. ${ }^{8}$ The therapeutic properties of $E$. alba are antioxidant, antihyperglycemic, Immunomodulator, antimytotoxic, analgesic, antihepatoxic, antibacterial and antihaemorrhagic for general virtue of health. Phytochemical studies on $E$. alba show the attendance of alkaloids like nicotine, ecliptine and bio-active steroidal alkaloids like ecliptalbine, dehydroverazine and verazine ${ }^{9}$, Many hydrocarbons like Ecliptal, $\alpha$-formyl terthienyl. $E$. alba have triterpenes along with six new oleanane triterpene glycosides and Eclalbasaponin, $\alpha$ and $\beta$ amyrin, oleanolic acid, Ursolic acid. ${ }^{10}$

\section{EXPERIMENTAL}

Collection/Selection and Identification of Plant Material

Eclipta alba full plant (Fig.-1) were collected from the Village \& Post-Libberheri, District- Haridwar Uttarakhand (INDIA) respectively in the month of March-April 2017. The herbarium was prepared for the authentication. The plant was authenticated form taxonomy Laboratory; Identified by Dr. R. M. Painuli, Department of Botany and Microbiology Hemvati Nandan Bahuguna Garhwal (A Central University) University Srinagar (Garhwal), Uttarakhand. The voucher specimen number GUH 20752 was deposited in the herbarium. Collected plants were shade dried at room temperature and ground separately to a moderately fine powder.

\section{Physico-chemical Analysis ${ }^{11-15}$}

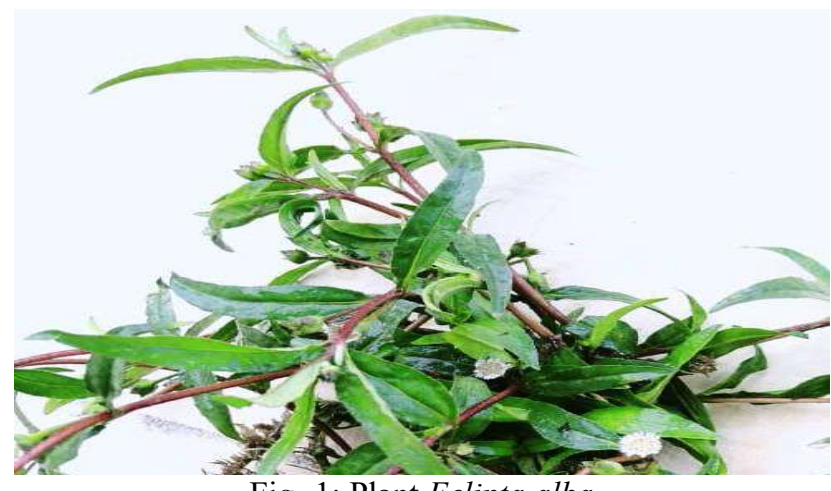

Fig.-1: Plant Eclipta alba

\section{Total Ash Value}

The $2.00 \mathrm{gm}$ air-dried whole plant material was ignited at temperature $450^{\circ} \mathrm{C}$. The ash was cooled in a desiccator and the weight of white ash corresponded to the ash or mineral matter.

\section{Water-soluble Ash}

Ash obtained and applied to the $30 \mathrm{ml}$ water, and then filtered for 5 minutes. The insoluble ash was deposited on ashless filter paper and washed with hot water and burned at $105^{\circ} \mathrm{C}$ and weight in the oven. The percentage of water-soluble ash with the relation to total ash was determined. 
RASĀYAN J. Chem.

Vol. 13 | No. 3 |1637-1643| July - September | 2020

\section{Acid insoluble Ash}

Complete ash obtained was boiled for 5 minutes with $25 \%$ dilute hydrochloric acids. The insoluble ash was collected ash-less filter paper and washed with hot water and ignited to an oven at a constant weight of $105^{\circ} \mathrm{C}$ temperature. The percentage of insoluble ash from acid was calculated with the total ash reference.

\section{Loss on Drying}

Approximately $25 \mathrm{~g}$ of plant weighing absolutely in an evaporating apparatus and hold in an oven at $105^{\circ}$ $\mathrm{C}$ until a fixed weight is obtained.

Loss of Drying $(\%)=$ Loss in weight $\times 100 / \mathrm{W}$

Where, $\mathrm{W}=$ Weight of plant material in gm

\section{Water Solubility}

In 24 hours the 2.00 gm full plant material was macerated in a closed flask with $100 \mathrm{ml}$ of distilled water. Flash frequently shocks in 6 hours, allowing me to quickly stand 18 hours, and Filter. The filtrate was moved to an evaporating platform and heated with a hot air oven at $105^{\circ} \mathrm{C}$ until the humid mass was found.

\section{Acid Solubility}

The 2.00 gm air-dried whole plant content was macerated within 24 hours in a closed flask with $100 \mathrm{ml}$ of 10 percent hydrochloric acid. Flash always shook in 6 hours allowing me to easily stand 18 hours and filter. The filtrate was transferred to an evaporating dish and heated at temperature $105^{\circ} \mathrm{C}$ with a hot air oven until the damp mass was detected.

\section{Base Solubility}

The 2.00 gm air-dried whole plant content was macerated in a closed flask in 24 hours with $100 \mathrm{ml}$ of 0.4 gm $\mathrm{NaOH}$ dissolve in $100 \mathrm{ml}$ distilled water. Flash open shook in 6 hours, allowing the same to easily stand 18 hours, and Filter. The filtrate was transferred to an evaporating platform and heated with a hot air oven at $105^{\circ} \mathrm{C}$ until the humid mass was found.

\section{Methanolic Solubility}

In 24 hours the $2.00 \mathrm{gm}$ dried full plant in a closed flask with $100 \mathrm{ml}$ of methanol. Flash often shook in 6 hours, allowing I to stand 18 hours and Filter rapidly. The filtrate was transferred to an evaporating platform and heated with a hot air oven at $105^{\circ} \mathrm{C}$ until the humid mass was found.

\section{Solubility of Ethyl Acetate}

In 24 hours the 2.00 gm air-dried whole plant material was macerated in a closed flask with $100 \mathrm{ml}$ of ethyl acetate. Flash often shook in 6 hours, allowing me to easily stand 18 hours and Filter. The filtrate was transferred to an evaporating platform and heated with a hot air oven at $105^{\circ} \mathrm{C}$ until the humid mass was found.

\section{Solubility of Chloroform}

In 24 hours the $2.00 \mathrm{gm}$ dried plant was macerated in a closed flask with $100 \mathrm{ml}$ of Chloroform. Flash often shook in 6 hours allowing me to easily stand 18 hours and Filter. The filtrate was transferred to an evaporating platform and heated with a hot air oven at $105^{\circ} \mathrm{C}$ until the humid mass was found.

\section{Solubility of Petroleum Ether}

In 24 hours the $2.00 \mathrm{gm}$ dried plant was macerated in a closed flask with a hundred $\mathrm{ml}$ of petroleum ether. Flash often shook in 6 hours allowing me to easily stand 18 hours and Filter. The filtrate was transferred to an evaporating platform and heated with a hot air oven at $105^{\circ} \mathrm{C}$ until the humid mass was found.

\section{Preparation of Plant Extract}

Air-dried whole Eclipta alba ground to moderately fine powder was extracted with n-Hexane, Chloroform, Ethyl acetate, Methanol and water in the increasing polarity of solvents for $72 \mathrm{Hrs}$ using 
soxhlet apparatus. Each extract was evaporated under reduced pressure to obtain a semi-solid mass using a rotary evaporator and then vacuum dried to yield a residue. ${ }^{16-18}$

Preliminary Phytochemical Analysis ${ }^{19-23}$

Preliminary phytochemical analysis was done for the screening of deferent kinds of secondary metabolites. The phytochemical investigation was performed by doing deferent qualitative chemical tests including testes for alkaloids, carbohydrates, glycosides, tannins, saponins, resins and flavonoids in deferent extracts of Eclipta alba.

\section{Test for Alkaloids}

The test solutions were prepared by dissolving extracts in dilute hydrochloric acid.

\section{Mayer's Test}

In a test tube $2 \mathrm{ml}$ of test solution was taken. Few drops of potassium mercuric iodide (Mayer's reagent) were added it produce a cream-colored precipitate. This confirmed the existence of alkaloids.

\section{Hager's Test}

The test solution was taken in a test tube. Hager's reagent (saturated picric acid solution) was then added to make the solution acidic and no yellow precipitate was obtained on the stand.

\section{Dragendorff's Test}

Dragendorff's reagent (potassium bismuth iodide) was gradually applied to the test tube the drug sample was taken. The mixture did not produce precipitate reddish brown which was on standing.

\section{Wagner's Test}

A few droplets of iodine-potassium iodide solution were applied to the test tube in the extract solution. Precipitate formation confirmed a lack of alkaloids.

\section{Test for Carbohydrate}

Molish's Test

A few drops of Molish reagent were applied on $5 \mathrm{ml}$ sample, and the tube was tilted and $1 \mathrm{ml}$ of sulphuric acid was gradually added through one side at the bottom of the test tube. Reddish violet ring formed in the presence of sugars, at the junction of the two layers.

\section{Fehling's Test}

$1 \mathrm{ml}$ of filtrate was boiled on a water bath with $1 \mathrm{ml}$ of each Fehling's solutions A and B. A red precipitate indicated the presence of reducing sugar.

\section{Test for Flavonoids}

Few magnesium turns and few drops of concentrated hydrochloric acid were added and boiled in red or orange-red color for $5 \mathrm{~min}$. gives the existence of flavonoids.

\section{Killar-Killani Test}

$1 \mathrm{ml}$ of glacial acetic acid containing traces of ferric chloride and $1 \mathrm{ml}$ of concentrated sulphuric acid were added to the test solution. Glycoside was indicated by the formation of reddish-brown color at the junction of two layers and the upper layer turned bluish-green.

\section{Legal Test}

A few drops of pyridine and sodium nitroprusside solution was added to the test solution and made alkaline with $\mathrm{NaOH}$ solution, the presence of glycoside was indicated by a pink or red color.

\section{Resin Test}

Few drops of acetic anhydride solution and $1 \mathrm{ml}$ of sulphuric acid were applied to $1 \mathrm{ml}$ of the test solution. The presence of resin suggests orange to yellow color.

\section{Saponin Test}

$1 \mathrm{ml}$ of the test solution was diluted to $20 \mathrm{ml}$ with distilled water and shows saponins attendance when shaken in a graduated flask for 15 minutes $2 \mathrm{~cm}$ foam sheets. 
RASĀYAN J. Chem.

Vol. 13 | No. 3 |1637-1643| July - September | 2020

\section{Test for Phenols}

Ferric chloride test: In $5 \mathrm{ml}$ of distilled water, few drops of 5 percent ferric chloride solution was added to $50 \mathrm{mg}$ of extract dissolved in. The presence of a phenolic compound indicates a dark green color.

\section{Physico-Chemical Analysis}

\section{RESULTS AND DISCUSSION}

Eclipta alba dry powder was used as a sample for all Physicochemical analysis. In these physicochemical tests, Table-1 shows the values of Loss on Drying in the fresh plant, Total ash value, water-soluble and acid-insoluble ash of Eclipta alba.

\begin{tabular}{c|c|c}
\multicolumn{2}{c}{ Table-1: Physico-Chemical Evaluation of Eclipta alba. } \\
\hline S. No. & Parameters Evaluated & Value $(\% \mathrm{w} / \mathrm{w})$ \\
\hline 1 & Loss on Drying & 85.5 \\
\hline 2 & Total ash value & 15.625 \\
\hline 3 & Water-soluble ash Value & 29.032 \\
\hline 4 & Acid insoluble ash Value & 26.984 \\
\hline
\end{tabular}

\section{Extractive Values}

Eclipta alba dry powder was used for extractive values. Table-2 showed the Acid and basic values were determined in hydrochloric acid and base in sodium hydroxides. Petroleum ether, Chloroform, ethyl acetate, methanol and water-soluble extractive values were calculated in percentage.

Table-2: Extractive Values of Eclipta alba.

\begin{tabular}{c|c|c}
\hline S. No. & Solvents & Value $(\% \mathrm{w} / \mathrm{w})$ \\
\hline 1 & Water Soluble extractive value & 20.6 \\
\hline 2 & Methanol Soluble extractive value & 8.4 \\
\hline 3 & Ethyl acetate soluble extractive value & 18.2 \\
\hline 4 & Chloroform soluble extractive value & 1.6 \\
\hline 5 & Petroleum ether soluble extractive value & 1.8 \\
\hline 6 & Acid solubility & 2.6 \\
\hline 7 & NaoH Solubility & 45.2 \\
\hline
\end{tabular}

\section{Phytochemical Evaluation of Eclipta alba}

Deferent phytochemical screening tests were performed on the extracts of the whole plant of Eclipta alba. n-Hexane, chloroform, ethyl acetate, methanol and water extract were used phytochemical tests for alkaloids, flavonoids, terpenoids, glycosides, carbohydrate and saponin. Table no. 3 presents the result of the presence and absence of phytochemicals.

Table-3: Phytochemical Screening of Eclipta alba.

\begin{tabular}{c|c|c|c|c|c}
\hline Phytoconstituents & n-hexane & Chloroform & Ethyl acetate & Methanol & Water \\
\hline Alkaloids & + & + & - & + & + \\
\hline Flavonoids & + & - & + & - & - \\
\hline Terpenoids & - & + & - & + & - \\
\hline Glycosides & + & + & - & + & - \\
\hline Carbohydrate & + & + & + & + & + \\
\hline Saponin & - & - & + & + & + \\
\hline
\end{tabular}

\section{Discussion}

The present research work emphasizes on the physicochemical, phytochemical evaluation of medicinal plant namely; Eclipta alba belonging to the family Asteraceae. The medicinal plant was taken from Village and Post- Libberheri, District- Haridwar, Uttarakhand India and research was done at the H.N.B. Garhwal (A Central University) Srinagar Garhwal. N-Hexane, Chloroform, ethyl acetate, Methanolic and water extracts of Eclipta alba was prepared. All extracts were subjected to phytochemical screening. The phytochemical analysis objective was the standardization of the natural traditionally used medicinal plant. In physicochemical testing, different values were obtained for powdered material of Eclipta alba following the standard testing procedures. ${ }^{24,25}$

Different ash values were determined to check the quality and purity of the powdered medicinal crude drug. Acid insoluble and water-insoluble ash value was obtained by boiling a small quantity of ash powder in an acid and water separately. After filtration, the filter paper on which water-insoluble and acid 
RASĀYAN J. Chem.

Vol. 13 | No. 3 |1637-1643| July - September | 2020

insoluble ash were present was ignited in the furnace and in this way, ash values were calculated. The values calculated for total ash, acid insoluble and water-insoluble ash for powdered material of Eclipta alba were $15.625,26.984$ and $29.032 \%$ respectively. These values showed that silica, calcium oxalate, carbonates, silicates and phosphates of sodium, calcium, potassium and magnesium were present in ash of Eclipta alba. The Eclipta alba powdered material has extractives of $20.6 \%$ water, 1.8 petroleum ether, 1.6 chloroform, 18.2 ethyl acetate soluble and $8.4 \%$ alcohol soluble. Eclipta alba was 2.6 acid and $45.2 \%$ base solubility.

Phytochemical tests were carried out for every the N-Hexane, Chloroform, ethyl acetate, Methanolic and water extracts of Eclipta alba by adopting standard procedures. ${ }^{26-29}$ Phytochemical tests determined the presence or absence of secondary metabolites in which alkaloids, flavonoids, terpenoids, saponins, steroids, tannins, phlobatannins, quinones and glycosides were present. Table 3 presents the results for the presence of secondary metabolites in the extracts of Eclipta alba. When phytochemical tests were performed for tannins, the blue color appeared which indicated the presence of tannins in Eclipta alba methanol and ethyl acetate extracts.

Tannins are polyphenols different from other natural phenols and soluble in water. Tannins can precipitate proteins such as gelatin and this property is called astringency. Tannins are from the important components involved in developing defense strategies by plants. Proantho cyanidins (condensed tannins) are reported for their anti-bacterial, anthelmintic and anti-herpetic activities and provides defense. ${ }^{30}$ Phlobatannins were absent in both extracts because when a chemical test was performed no red color precipitate deposition was observed. Chemical tests performed for saponins on extracts of Eclipta alba revealed that only methanolic extract shows positive results which were indicated by stable soap formation. Plant saponins are soluble in water, have the property of stable soap formation on shaking and are glycosides of both triterpenes and sterols. Years ago, saponins were used as natural detergents and fish poison. Plants saponins were also reported for biological activities such as spermicidal, molluscicidal, antimicrobial, anti-inflammatory and cytotoxic. ${ }^{31-33}$

For the determination of the presence of flavonoids in the Eclipta alba extracts chemical test was performed and the appearance of yellow color which disappeared on standing was the evidence for the presence of flavonoids in both extracts. Flavonoids exhibit anti-oxidant properties. The anti-oxidant property of flavonoids against different oxidants was described by Larson (1988). Steroids present in extracts were analyzed by a colour change of extract after chemical treatment from violet to blue or green. Wagner's reagent was used for alkaloids determination and its presence was judged by a reddish-brown precipitate. Experiments showed that nitrogen-containing compounds like alkaloids have a potent inhibitory effect on different oxidative procedures. ${ }^{34}$ The presence of terpenoids was evaluated by a reddish-brown ring formation and was present in the methanolic extract of Eclipta alba. Terpenoids present in plants were extensively used because of their aromatic qualities and have a role in traditional herbal remedies. Cardiac glycosides were present in the Eclipta alba extracts when chemical tests were performed.

\section{CONCLUSION}

Physiochemical ash analysis of Medicinal plants is a quality control parameter, Total ash content revealed with the Physiological and Non- Physiological ash, was found to be higher in Eclipta alba. Studies conclude that, the following study helps to check the quality and purity of different Physico-chemical and phyto-chemical analysis of the plant species. These studies will be utilized in determining plant's character, the effect of plant species towards environmental changes and prepration of Herbal formulations etc.

\section{REFERENCES}

1. D.A. Pasquale, Journal of Ethnopharmacol, 11(1), 1(1984).

2. J.A.O. Ojewole, Journal of Ethnopharmacol, 99(1), 13(2005), DOI:10.1016/j.jep.2005.01.025

3. A. Kamboj and A.K. Saluja, International Journal of Green Pharmacy, 2, 59(2008), DOI: http://dx.doi.org/10.22377/ijgp.v2i2.29

4. G.C. Jagetia, A. Shirwaikar, S. K. Rao and P.M. Bhilegaonkar, Journal of pharmacy and Pharmacology, 55,1151(2003),DOI:10.1211/0022357021576 
RASĀYAN J. Chem.

Vol. 13 | No. 3 |1637-1643| July - September | 2020

5. D.F.A. Mendonca, D.K.F. Silva and D.K.K. Santos, Fitoterapia, 76, 629(2005), DOI: 10.1016/j.fitote.2005.06.013

6. T.T. Ayele, Organic Chemistry: Current Research, 7(2), 2(2018), DOI: 10.4172/2161-0401.1000192

7. B.B. Sahu and B.P. Shaw, BMC Plant Biology, 9(1), 1(2009), DOI:10.1186/1471-2229-9-69

8. V.k. saraswat, S. verma, S.V. Musaleand M. L. Jaiswal, International Ayurvedic Medical Journal, 3(8), 2462(2015).

9. S. Kumar, V.J. Kumar and R. Singh, Remarking an Analisation, 3(12 part 2), E56(2019).

10. S.A. Bhalerao, D.R. Verma, N.C. Teli and V.R. Murukate, International Journal of Bioassays, 2(11), 1443(2013).

11. V.V. Bhargava, A.K. Saluja and K.K. Dholwani, Journal of Pharmacognosyand Phytochemistry, 1(6), 61(2013).

12. J. Nisha, N. Anbu, P. Parthibhan and K. Kanakavalli, International Journal of Medical Research and Pharmaceutical Sciences, 4(10), 55(2017), DOI:10.5281/zenodo. 1009060

13. S. Abbas, H. Saleem, M.S.A. Gill, A.M. Bajwa, A. Sarwar and M.O. Omer, Academia Journal of Medicinal Plants, 4(8), 001(2016), DOI:10.15413/ajmp.2016.0108

14. M. Pande and K.B. Mohammed, Herbal Medicine: Open Access, 5(1:3), 1(2019), DOI: 10.21767/2472-0151.100041

15. R. K. Chaudhari and N.O. Girase, Journal of Chemical and Pharmaceutical Research, 7(8), 657(2015).

16. S. Chandra, S. Saklani and S. Kumar, World Journal of Pharmaceutical Sciences, 4(5), 273(2016).

17. B. Cahyono, J. Ariani, H. Failasufa, M. Suzery, S. Susanti and H. Hadiyanto, Rasayan Journal of Chemistry, 12(1), 7(2019), DOI:10.31788/RJC.2019.1213092

18. A. Singh and M. Gupta, Rasayan Journal of Chemistry, 11(1), 228(2018), DOI: $10.7324 /$ RJC.2018.1111999

19. O.V. Njoku and C. Obi, African Journal of Pure and Applied Chemistry, 3(11), 228(2009).

20. O.O. Odebiyi and E. Sofowora, Lloydia, 41(3), 234(1977).

21. Yuandani, S. Yuliasmi, D. Satria, R.F. Dongoran, M.S. Sinaga and N.H.A. Marpaung, Rasayan Journal of Chemistry, 12(1), 1(2019), DOI:10.31788/RJC.2019.1215050

22. D.R. Jenifer and B.R. Malathy, Rasayan Journal of Chemistry, 12(2), 630(2019), DOI: $10.31788 /$ RJC.2019.1225134

23. N.M. Saptarini and G. Hadisoebroto, Rasayan Journal of Chemistry, 13(2), 789(2020), DOI: $10.31788 /$ RJC.2020.1325533

24. B. Janaki, R. Sashidhar, A Potential Food Additive, Food Chemistry, 61(1), 231(1998).

25. M. Saleem, M. Karim, M.I. Qadir, B. Ahmed, M. Rafiq and B. Ahmad, Bangladesh Journal of Pharmacology, 9(2), 189(2014), DOI:10.3329/bjp.v9i2.17859

26. B. Obadoni and P.O. Ochuko, Global Journal of Pure Applied Sciences, 8(2), 203(2002), DOI: 10.4314/gjpas.v8i2.16033

27. O.O. Odebiyi and E.A.Sofowora, Lloydia, 41(3), 234(1978).

28. J. Parekh, S. Chanda, Afarecan Journal Biomed. Research, 10(2), 175(2007), DOI: 10.4314/ajbr.v10i2.50624

29. U. Saleem, K. Hussain, M. Ahmad, I.N. Bukhari, A. Malik and B. Ahmad, Pakistani Journal of Pharmaceutical Sciences, 27(3), 577(2014).

30. R.A. Dixon, D.Y. Xie and S.B. Sharma, New Phytologist, 65(1), 9(2005), DOI:10.1111/j.14698137.2004.01217.x

31. S.B. Mahato, S.K. Sarkar and G. Poddar, Phytochemistry, 27(10), 3037(1988).

32. A. Marston and K. Hostettmann, Phytochemistry, 24(4), 639(1985), DOI:10.1016/S00319422(00)84870-0

33. B. Setty, V. Kamboj, H. Garg and N. Khanna, Contraception, 14(5), 571(1976), DOI: 10.1016/00107824(76)90008-1

34. R. A. Larson, Phytochemistry, 27(4), 969(1988), DOI:10.1016/0031-9422(88)80254-1

[RJC-5911/2020] 